\title{
Pengaruh Harga Jual dan Saluran Distribusi Terhadap Peningkatan Volume Penjualan Paket Internet Telkomsel 15 GB Pada CV. Sinar Telekom Lahat
}

\author{
Kasinem \\ Sekolah Tinggi Ilmu Ekonomi Serelo Lahat, kasinem.stie@gmail.com
}

\begin{abstract}
ABSTRAK
Penelitian ini bertujuan untuk mengetahui Pengaruh Harga Jual dan Saluran Distribusi terhadap Volume Penjualan Paket internet Telkomsel 15GB pada CV. Sinar Telekom Lahat. Hasil perhitungan diperoleh $Y=1960-0,20 X 1+0,90 X 2+e$, yang artinya jika Harga Jual $(X 1)$ dinaikkan 0,20 satu unit maka Volume Penjualan akan meningkat 0,20 dan sebaliknya jika Saluran Distribusi (X2) ) meningkat 0,90 satu unit maka Volume Penjualan akan meningkat 0,90. Nilai Adjust R Square sebesar 0,979 atau $97,9 \%$ yang artinya variabel bebas mempunyai kontribusi atau kontribusi terhadap variabel terikat sebesar $97,9 \%$ sedangkan 2,1\% dipengaruhi oleh faktor lain yang tidak diteliti oleh penulis. Uji Harga Jual (X1) dan Saluran Distribusi (X2) paket internet Telkomsel 15GB di CV. Sinar Telekom Lahat dengan menggunakan uji parsial diperoleh nilai thitung untuk variabel Harga Jual -3,894 dengan tingkat signifikansi 0,060, maka Ho diterima dan Ha ditolak yang menunjukkan tidak terdapat pengaruh yang signifikan antara Harga Jual dan Volume Penjualan. Pengujian variabel Saluran Distribusi dengan pengujian parsial diperoleh thitung sebesar 9,599 dengan nilai signifikansi 0,011 maka Ho ditolak dan Ha diterima yang menunjukkan terdapat pengaruh yang signifikan antara Saluran Distribusi terhadap Volume Penjualan paket internet Telkomsel 15GB pada CV. Sinar Telekom Lahat. Hasil uji $\mathrm{F}$ diperoleh nilai $=47.600$ dengan mengambil taraf signifikan $5 \%$ kemudian dengan taraf signifikan 0,021 maka Ho ditolak dan Ha diterima. Artinya dapat disimpulkan bahwa terdapat hubungan linier antara Harga Jual (X1) dan Saluran Distribusi (X2) secara bersama-sama terhadap Volume Penjualan paket internet Telkomsel 15GB pada CV. Sinar Telekom Lahat.
\end{abstract}

Kata Kunci: Harga Jual, Saluran Distribusi, Penjualan Volume

\section{ABSTRACT}

This study aims to determine the effect of Selling Prices and Distribution Channels on Sales Volume of Telkomsel internet package 15GB on CV. Sinar Telekom Lahat. The calculation results obtained $Y=$ $1960-0.20 X 1+0.90 X 2+e$, which means that if the Selling Price $\left(X_{1}\right)$ is increased by 0.20 one-unit, the Sales Volume will increase by 0.20 and vice versa if the Distribution Channels $\left(X_{2}\right)$ increased by 0.90 one-unit then the Sales Volume will increase by 0.90. The value of Adjust $R$ Square is 0.979 or $97.9 \%$ which means the free variable has a contribution or contribution to the dependent variable of $97.9 \%$ while $2.1 \%$ is influenced by other factors not examined by the author. Selling Price Test $\left(X_{1}\right)$ and Distribution Channel $\left(X_{2}\right)$ Telkomsel 15GB internet package on the CV. Sinar Telekom Lahat by using partial test, the tcount value for the Selling Price variable is $-3,894$ with a significance level of 0.060 , then Ho is accepted and Ha is rejected, which indicates there is no significant effect between the Selling Price and Sales Volume. Testing the Distribution Channel variable with partial testing obtained a tcount of 9.599 with a significance value of 0.011 then Ho was rejected and Ha was received which showed there was a significant influence between the Distribution Channels on the Sales Volume of the Telkomsel 15GB internet package on the CV. Sinar Telekom Lahat. F test results obtained value $=47,600$ by taking a significant rate of $5 \%$ then with a significant level of 0.021 then Ho is rejected and $\mathrm{Ha}$ is accepted. This means that it can be concluded that there is a linear relationship between the Selling Price $\left(X_{1}\right)$ and Distribution Channel $\left(X_{2}\right)$ together to the Sales Volume of Telkomsel internet package 15GB on CV. Sinar Telekom Lahat.

Keywords: Selling Price, Distribution Channels, Sales Volume 


\section{A. PENDAHULUAN}

Di era globalisasi sekarang ini Manajemen Pemasaran merupakan suatu disiplin ilmu yang memiliki arti yang sangat penting dalam dunia usaha. Para pelaku bisnis diharapkan untuk menciptakan suatu differensiasi unik dan posisi yang jelas sehingga konsumen dapat membedakan dengan para pesaingnya. Para pelaku bisnis atau perusahaan harus menyiapkan strategi agar dapat membangun rasa antusias konsumen menjadi suatu penelitian didalam mengkonsumsi produk dan jasa, sehingga akan membuat mereka merasa terkesan.

CV. Sinar Telekom Lahat adalah perusahaan yang bergerak dalam bidang Telekomunikasi terbesar di Sumatera, perusahaan CV. Sinar Telekom juga merupakan bagian dari Deller Telkomsel Indonesia. Namun setelah dilihat secara langsung pada CV. Sinar Telekom paket internet telkomsel 15GB belum mencapai target penjualan karena banyaknya persaingan pada setiap perusahaan lainnya. Dan perusahaan tidak mendapatkan profit yang besar dalam penjualan paket internet telkomsel 15GB dikarenakan harga jual promo pada paket 15GB lebih murah dari harga biasanya. Karena banyaknya persaingan penjualan pada paket internet antar perusahaan yang dapat menurunkan pertumbuhan perusahaan pada penjualan paket internet telkomsel 15GB.

Dalam meningkatkan persaingan masing-masing perusahaan harus dapat memenangkan persaingan tersebut dengan menampilkan produk yang terbaik dan dapat memenuhi selera konsumen yang selalu berkembang dan berubah-ubah. Untuk memenangkan persaingan yang semakin kompetitif para pelaku usaha diharapkan untuk mampu menciptakan keunggulan bersaing atas produk dan layanan dalam upaya memuaskan pelanggan. Tanpa adanya konsumen setiap perusahaan akan kehilangan pendapatannya yang berakibat pada jatuhnya bisnis tersebut.

Paket internet atau kuota internet merupakan kebutuhan pokok di era globalisasi modern seperti sekarang ini. Paket internet merupakan batasan yang diberikan operator yang digunakan untuk akses internet. Biasanya satuan yang digunakan adalah kilobyte $(\mathrm{kb})$, megabyte $(\mathrm{mb})$, dan gigabyte ( $\mathrm{gb}$ ). Paket internet sudah menjadi kebutuhan pokok baik dari kalangan muda hingga dewasa. Namun, dengan banyaknya persaingan harga jual pada paket internet dapat menjadi pemicu pada peningkatan volume penjualan paket internet tersebut.

Harga jual merupakan besarnya harga yang dibebankan kepada konsumen yang diperoleh atau dihitung dari biaya produksi ditambah biaya nonproduksi dan laba yang diharapkan. Harga jual adalah sejumlah kompensasi (uang ataupun barang) yang dibutuhkan untuk mendapatkan sejumlah kombinasi barang atau jasa. Perusahaan selalu menetapkan harga produknya dengan harapan produk tersebut laku terjual dan memperoleh laba yang maksimal.

Saluran Distribusi adalah seperangkat lembaga yang melakukan semua kegiatan (fungsi) pemindahan barang dari tangan produsen ke tangan konsumen akhir.

Volume penjualan merupakan jumlah pada setiap produk atau jasa yang dapat dijual. Volume penjualan merupakan ukuran yang menunjukan banyaknya atau besarnya jumlah barang atau jasa yang terjual.

Namun setelah dilihat secara langsung pada CV. Sinar Telekom Lahat paket internet telkomsel 15GB belum mencapai target penjualan karena banyaknya persaingan pada setiap perusahaan lainnya. Karena banyaknya persaingan 
penjualan pada paket internet antar perusahaan yg dapat menurunkan pertumbuhan perusahaan pada penjualan paket internet telkomsel 15GB.

Tabel Data Penjualan CV. Sinar Telekom Lahat

\begin{tabular}{ccccc}
\hline Tahun & Harga & $\begin{array}{c}\text { Saluran } \\
\text { Distribusi }\end{array}$ & $\begin{array}{c}\text { Volume } \\
\text { Penjualan } \\
\text { (thn) }\end{array}$ & $\begin{array}{c}\text { Target } \\
\text { Penjualan } \\
\text { (thn) }\end{array}$ \\
\hline 2016 & Rp. 76.000 & 3 & 700 pcs & 720 pcs \\
2017 & Rp. 74.000 & 3 & 750 pcs & 720 pcs \\
2018 & Rp. 76.000 & 3 & 720 pcs & 720 pcs \\
2019 & Rp. 76.500 & 4 & 790 pcs & 720 pcs \\
2020 & Rp. 75.000 & 4 & 820 pcs & 720 pcs \\
\hline
\end{tabular}

Sumber: CV. Sinar Telekom Lahat 2021

Dari tabel diatas dapat ditarik kesimpulan bahwa:

1. Paket Internet Telkomsel 15GB ada yang sudah mencapai target penjualan dan ada yang belum mencapai target penjualan. Hal ini dikarenakan kurangnya evaluasi guna untuk memecahkan masalah dan mencari solusi.

2. Perusahaan tidak mendapatkan profit yang besar dalam penjualan paket internet telkomsel 15GB dikarenakan harga jual yang lebih murah dan pencapaian volume penjualan yang masih mengalami penurunan pada paket internet telkomsel 15GB. Pada tahun 2016 harga kartu paket telkomsel 15GB yaitu Rp. 76.000 dengan target penjualan 720 pcs pertahun dengan volume penjualan 700 pcs pertahun. Pada tahun 2017 harga kartu paket telkomsel 15GB yaitu Rp. 74.000 dengan target penjualan 720 pcs pertahun dan tercapai volume penjualan 750 pcs pertahun. Pada tahun 2018 harga kartu paket telkomsel 15GB yaitu Rp. 76.000 dengan target penjualan 720 pcs pertahun dan tercapai volume penjualan 720 pcs pertahun. Pada tahun 2019 harga kartu paket telkomsel 15GB yaitu Rp. 76.500 dengan target penjualan 720 pcs pertahun dan tercapai volume penjualan 790 pcs pertahun. Dan Pada tahun 2020 harga kartu paket telkomsel 15GB yaitu Rp. 75.000 dengan target penjualan 720 pcs pertahun dan tercapai volume penjualan 820 pcs pertahun.

3. Banyaknya persaingan penjualan paket internet antar perusahaan yang dapat menurunkan pertumbuhan perusahaan pada penjualan paket internet telkomsel 15GB seperti terjadi pada saluran distribusi tahun 2016 - 2018 langsung dari Produsen ke Agen (CV. Sinar Telekom) ke Konsumen, sedangkan pada tahun 2019 dan 2020 saluran distribusi dari Produsen ke Agen (CV. Sinar Telekom) ke Outlet lalu ke Konsumen gunanya untuk meningkatkan volume penjualan.

\section{B. KAJIAN TEORI}

\section{Pengertian Pemasaran}

Inti dari pemasaran adalah mengidentifikasikan dan memenuhi kebutuhan dan keinginan konsumen. pemasaran menurut Kotler dan Keller (2016:27) adalah "marketing is meeting needs profitability", maksud ungkapan tersebut adalah pemasaran merupakan hal yang dilakukan untuk memenuhi setiap kebutuhan (kebutuhan konsumen) dengan cara-cara yang menguntungkan semua pihak. 


\section{Pengertian Harga Jual}

Kotler dan Amstrong (2016:324) mendefinisikan bahwa: Harga jual merupakan sejumlah uang yang dikeluarkan untuk sebuah produk atau jasa, atau sejumlah nilai yang ditukarkan oleh konsumen untuk memperoleh manfaat atau kepemilikan atau penggunaan atas sebuah produk atau jasa.

\section{Indikator Harga Jual}

Menurut Kotler dan Amstrong (2016:78) terdapat 4 indikator harga jual yaitu:

a) Keterjangkauan Harga

Konsumen bias menjangkau harga yang telah ditetapkan oleh perusahaan. Produk biasanya ada beberapa jenis dalam satu merk harganya berbeda dari yang termurah sampai termahal.

b) Kesesuaian Harga dengan Kualitas Produk

Harga sering dijadikan sebagai indikator kualitas bagi konsumen, orang sering memilih harga yang lebih tinggi diantara dua barang karena mereka melihat adanya perbedaan kualitas. Apabila harga lebih tinggi orang cenderung beranggapan bahwa kualitasnya juga lebih baik.

c) Kesesuaian Harga dengan Manfaat

Konsumen memutuskan membeli suatu produk jika manfaat yang dirasakan lebih besar atau sama dengan yang telah dikeluarkan untuk mendapatkannya. Jika konsumen merasakan manfaat produk lebih kecil dari uang yang dikeluarkan maka konsumen akan beranggapan bahwa produk tersebut mahal dan konsumen akan berpikir dua kali untukmelakukanpembelian.

d) Daya Saing Harga

Konsumen sering membandingkan harga suatu produk dengan produk lainnya. Dalam hal ini mahal murahnya suatu produk sangat dipertimbangkan oleh konsumen pada saat akan membeli produk tersebut.

\section{Pengertian Saluran Distribusi}

Menurut Kotler dan Amstrong (2016:160) saluran distribusi adalah kumpulanperusahaan atau individu yang bertanggung jawab atau membantu dalam pendistribusian sesuatu berupa barang atau jasa dengan memindahkannya dari produsen ke konsumen akhir atau konsumen industri. Saluran distribusi memiliki pengaruh penting dalam kegiatan perdagangan. Saluran distribusi inilah yang menjadi perantara khusus antara para konsumen dengan para produsen. Artinya, tanpa adanya saluran distribusi, maka barang-barang yang diproduksi oleh produsen tidak bisa sampai ke tangan konsumen.

\section{Indikator Saluran Distribusi}

Indikator saluran distribusi menurut Kotler dan Amstrong dalam Suparyanto dan Rosad (2015:160-162) adalah sebagai berikut:

$>\quad$ Sistem Transportasi

Berkaitan dengan cara pengiriman atau penyaluran produk.

$>\quad$ Ketersediaan produk Jumlah produk yang tersedia dari perusahaan bagi konsumen.

Waktu penantian

Lamanya penantian produk yang diinginkan konsumen. 


\section{Pengertian Volume Penjualan}

Menurut Francis Tantri dan Thamrin (2016:3) Volume Penjualannya itu termasuk bagian dari promosi dan promosi adalah salah satu bagian dari keseluruhan sistem pemasaran.

Bahwa penjualan adalah aktivitas maupun kegiatan yang dilakukan manusia yang saling menguntungkan satu sama lain, dimana penjual menawarkan produk yang dimiliki pada konsumen sehingga mampu menarik kecenderungan konsumen tersebut untuk sedia mengeluarkan uang guna membeli suatu produk yang telah ditawarkan oleh penjual.

Volume penjualan merupakan perolehan yang didapatkan perusahaan dengan cara salesman yang telah berhasil menjual produk yang dihasilkan.

\section{Indikator Volume Penjualan}

Indikator volume penjualan menurut Kotler dalam Basu Swasta dan Irwan (2014 : 423) adalah:

a) Mencapai volume penjualan

Suatu perusahaan harus memiliki strategi pemasaran yang baik untuk dapat memasarkan produknya kepada masyarakat, strategi yang baik dan matang berguna untuk mencapai target penjualan. Kemampuan perusahaan menjual produknya menentukan keberhasilan dan tingkatan penjualan yang dicapai oleh perusahaan.

b) Mendapat laba tertentu

Perusahaan harus memiliki kemampuan dalam mendapatkan profit yang besar sehingga investor dapat menanamkan modalnya. Penanaman modal yang dilakukan investor berguna untuk memperluas usaha perusahaan. Hal ini harus dilakukan oleh perusahaan untuk dapat mencapai target laba sehingga perusahaan mendapatkan profit yang signifikan.

c) Menunjang pertumbuhan perusahaan

Perusahaan memiliki kemampuan dalam menjual produk yang dapat meningkatkan volume penjualan. Hal ini berguna bagi perusahaan dalam menunjang pertumbuhan perusahaan. Sehingga keberlangsungan perusahaan dapat bertahan ditengah persaingan antar perusahaan.

\section{Kerangka Konsep Penelitian}

Kerangka pemikiran merupakan model konseptual tentang bagaimana teori berhubungan dengan berbagai faktor yang telah diidentifikasi sebagai masalah penting. Variabel $X$ dalam penelitian ini antara lain: variabel $X_{1}$ Harga Jual dan variabel $X_{2}$ adalah Saluran Distribusi. Sedangkan variabel $Y$ menurut Sugiyono (2017:55) merupakan variabel terikat atau variabel yang dipengaruhi, yaitu Volume Penjualan. Kerangka pemikiran penelitian dapat dilihat pada gambar berikut: 


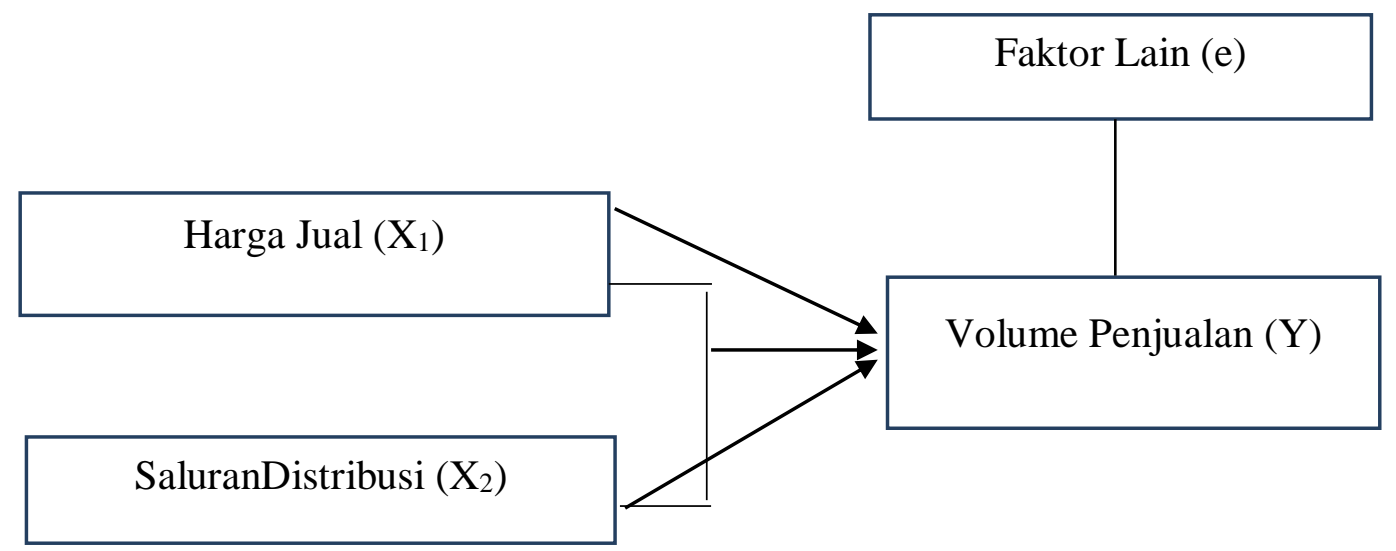

\section{Gambar Kerangka Pemikiran}

Keterangan:

$\mathrm{X}_{1} \quad$ : HargaJual (Variabel Bebas)

$\mathrm{X}_{2} \quad$ : SaluranDistribusi (Variabel Bebas)

Y : Volume Penjualan (Variabel Terikat)

e : Faktor Lain

\section{Hipotesis}

Hipotesis merupakan jawaban sementara terhadap rumusan masalah penelitian. Jadi hipotesis juga dapat dinyatakan sebagai jawaban teoritis terhadap rumusan masalah penelitian. Berdasarkan penelitian tersebut maka hipotesis dalam penelitian ini adalah :

1. Di duga Harga Jual berpengaruh signifikan terhadap peningkatan Volume Penjualan paket internet telkomsel 15GB pada CV. Sinar Telekom Lahat

2. Di duga Saluran Distribusi berpengaruh signifikan terhadap peningkatan Volume Penjualan paket internet telkomsel 15GB pada CV. Sinar Telekom Lahat

3. Di duga Harga Jual dan Saluran Distribusi secara bersama-sama berpengaruh signifikan terhadap peningkatan Volume Penjualan paket internet telkomsel 15GB pada CV. Sinar Telekom Lahat.

\section{METODELOGI PENELITIAN}

Dalam penelitian ini peneliti menggunakan jenis Penelitian Deskriptif Kuantitatif. Pada pendekatan deskriptif ini penelitian yang dilakukan untuk mengetahui variabel mandiri, baik satu variabel atau lebih, sehingga dalam penelitian ini peneliti tidak membuat perbandingan variabel pada sampel yang lain dan mencari hubungan variabel dengan variabel yang lainnya.

Pada pendekatan kuantitatif yang digunakan untuk penelitian adalah populasi sampel tertentu, teknik pengumpulan data menggunakan instrumen penelitian, analisa data bersifat kuantitatif / statistik yang bertujuan untuk menguji hipotesa yang telah ditetapkan.

\section{Populasi dan Sampel}

Menurut Sugiyono (2017:80), definisi populasi adalah sebagai berikut: "Populasi adalah wilayah generalisasi yang terdiri atas obyek/subyek yang mempunyai kualitas dan karakteristik tertentu yang ditetapkan oleh peneliti untuk dipelajari dankemudian ditarik kesimpulannya". Adapun yang menjadi populasi dalam penelitian ini adalah data harga jual dan saluran distribusi serta data volume 
penjualan dari tahun 2016 sampai tahun 2020.Data yang digunakan adalah time series atau deret waktu yaitu sekumpulan data dari suatu fenomena tertentu misalnya dalam waktu mingguan, bulanan, maupun tahunan. Sampel yang digunakan dalam penelitian ini adalah data harga jual, saluran distribusi, dan volume penjualan dalam 5 tahun terakhir yaitu dari tahun 2016 sampai tahun 2020 .

\section{Sumber Data}

Sumber data yang di gunakan dalam penelitian ini adalah data primer data ini diperoleh langsung dari obyek penelitian yaitu seluruh data harga, saluran distribusi dan penjualan paket internet 15 GB CV Sinar Telekom Lahat dari tahun 2016 sampai dengan 2020.

\section{Metode Analisis Data}

Analisis yang akan digunakan dalam penelitian ini adalah analisis kuantitatif, Menurut Sugiono (2013:7) alat analisis yang bersifat kuantitati pada alat yang mengunakan data penelitian berupa angka-angka dan analisis menggunakan statistik dan hasil yang disajikan berupa angka-angka yang kemudian di uraikan atau dijelaskan atau di interprestasikan dalam suatu uraian. Analisis kuantitatif yang digunakan dalam penelitian ini adalah regresi linier berganda, Koefisien determinasi, uji parsial dan uji simultan.

\section{HASIL DAN PEMBAHASAN}

\section{Uji Koefisien Regresi Linier Berganda}

Analisis regresi linier berganda pada penelitian ini dapat dilihat pada hasil SPSS sebagai berikut:

\section{Tabel Regresi Linier Berganda Coefficients $^{\mathrm{a}}$}

\begin{tabular}{llllll}
\hline & \multicolumn{2}{l}{$\begin{array}{l}\text { Unstandardized } \\
\text { Coefficients }\end{array}$} & \multicolumn{2}{l}{$\begin{array}{l}\text { Standardized } \\
\text { Coefficients }\end{array}$} & \\
Model & B & $\begin{array}{l}\text { Std. } \\
\text { Error }\end{array}$ & Beta & t & Sig. \\
\hline $1 \quad$ (Constant) & 1960,000 & 381,747 & & 5,134 &, 036 \\
harga jual &,- 020 &, 005 &,- 406 & $-3,894$ &, 060 \\
saluran distribusi & 90,000 & 9,376 & 1,000 & 9,599 &, 011 \\
\hline
\end{tabular}

a. Dependent Variable: volume penjualan

Sumber : data diolah melalui data spss

Berdasarkan hasil pengolahan data menggunakan SPSS seperti yang telah disajikan pada tabel diatas, persamaan regresi yang didapat adalah:

\section{$Y=1960-0,20 X_{1}+0,90 X_{2}+e$}

Persamaan tersebut dapat disimpulkan bahwa bila tanpa adanya variabel harga jual $\left(X_{1}\right)$, variabel saluran distribusi $\left(X_{2}\right)$ maka nilai volume penjualan sebesar 1960 .

Apabila variabel harga jual $\left(X_{1}\right)$ dinaikkan satu-satuan maka akan meningkatkan sementara variabel volume penjualan $(Y)$ sebesar $(-0,20)$ 
- Apabila saluran distribusi $\left(\mathrm{X}_{2}\right)$ dinaikan satu-satuan maka akan meningkatkan sementara variabel volume penjualan $(Y)$ sebesar 0,90 .

\section{Koefisien Determinasi}

Koefisien determinasi digunakan untuk mengetahui seberapa besar kontribusi variabel harga jual $\left(X_{1}\right)$ dan variabel saluran distribusi $\left(X_{2}\right)$ terhadap volume penjualan (Y). Nilai uji determinasi dapat dilihat dari tabel hasil olah data dengan menggunakan SPSS pada tabel model summary.

\section{Tabel Koefisien Determinasi Model Summary}

\begin{tabular}{lllll} 
Model & $\mathrm{R}$ & $\begin{array}{l}\mathrm{R} \\
\text { Square }\end{array}$ & $\begin{array}{l}\text { Adjusted } \\
\text { Square }\end{array}$ & $\mathrm{R}$ \\
\hline 1 &, $990^{\mathrm{a}}$ &, 979 &, 959 & Std. Error of the Estimate \\
\hline
\end{tabular}

a. Predictors: (Constant), saluran distribusi, harga jual

b. Dependent Variable: volume penjualan

Sumber : data diolah melalui data spss

Besarnya nilai koefisien determinan $\left(\mathrm{r}^{2}\right)$ berdasarkan tabel pengolahan data SPSS diatas sebesar 97,9. Artinya variabel volume penjualan paket internet telkomsel 15GB pada CV. Sinar Telekom Lahat dapat dijelaskan oleh variabel harga jual dan saluran distribusi dengan kontribusi 97,9\% sedangkan sisanya 2,1 dapat dijelaskan variabel lain yang tidak dimasukkan dalam model penelitian ini.

\section{Uji Parsial (Uji T)}

Uji hipotesis ini dilakukan dengan menggunakan nilai t hitung dengan t tabel. Nilai $\mathrm{t}$ hitung dapat dilihat pada hasil pengolahan data SPSS tabel coefficient.

\section{Tabel Uji T}

Coefficients $^{\mathrm{a}}$

\begin{tabular}{|c|c|c|c|c|c|}
\hline \multirow[b]{2}{*}{ Model } & \multicolumn{2}{|c|}{$\begin{array}{l}\text { Unstandardized } \\
\text { Coefficients }\end{array}$} & \multicolumn{2}{|c|}{$\begin{array}{l}\text { Standardized } \\
\text { Coefficients }\end{array}$} & \multirow[b]{2}{*}{ Sig. } \\
\hline & $B$ & $\begin{array}{l}\text { Std. } \\
\text { Error }\end{array}$ & Beta & $t$ & \\
\hline \multirow{3}{*}{$\begin{array}{ll}1 & \text { (Constant) } \\
& \text { harga jual } \\
\text { saluran distribusi }\end{array}$} & 1960,000 & 381,747 & & 5,134 & ,036 \\
\hline &,- 020 & ,005 &,- 406 & $-3,894$ & ,060 \\
\hline & 90,000 & 9,376 & 1,000 & 9,599 & ,011 \\
\hline
\end{tabular}

a. Dependent Variable: volume penjualan

Sumber : data diolah melalui data spss

Nilai $t$ tabel dengan tingkat signifikan 5\% dengan degress of freedom (df) dengan dk pembilang 3 dan dk penyebut 5, maka t tabel adalah 2,919. Dengan membandingkan nilai t hitung dan t tabel maka dapat disimpulkan:

a. Variabel harga jual dengan t hitung $<$ t tabel atau $-3,894<2,919$ dan dengan nilai signifikan (sig) $0,060>0,050$ maka Ho diterima dan $\mathrm{Ha}$ ditolak, hal ini 
menunjukkan bahwa tidak terdapat pengaruh yang signifikan antara harga jual dan volume penjualan paket internet telkomsel 15GB pada CV. Sinar Telekom Lahat

b. Variabel saluran distribusi dengan $t$ hitung $>t$ tabel atau 9,599 $>2,919$ dandengannilaisignifikan (sig) 0,011>0,050 maka Ho ditolak dan Ha diterima, hal ini menunjukkan bahwa terdapat pengaruh signifikan antara saluran distribusi dan volume penjualan paket internet telkomsel 15GB pada CV. Sinar Telekom Lahat

\section{Uji Simultan (Uji F)}

Uji hipotesis simultan digunakan untuk mengetahui apakah harga jual dan saluran distribusi mempunyai pengaruh atau tidak terhadap volume penjualan. Nilai $\mathrm{F}$ hitung dapat dilihat dari hasil pengolahan data yang menggunakan SPSS pada tabel Anova sebagai berikut.

ANOVA $^{a}$

Tabel Uji Simultan

\begin{tabular}{llrlll}
\hline Model & Sum & of & Mean & & Sig. \\
& Squares & Df & Square & $F$ & S \\
\hline $1 \quad$ Regression & 9520,000 & 2 & 4760,000 & 47,600 & \\
$\begin{array}{l}\text { Residual } \\
\quad 200,000\end{array}$ & 2 & 100,000 & & \\
$\quad$ Total & 9720,000 & 4 & & & \\
\hline
\end{tabular}

a. Dependent Variable: volume penjualan

b. Predictors: (Constant), saluran distribusi, harga jual

Sumber : data diolah melalui data spss

Uji hipotesis simultan dilakukan dengan membandingkan nilai $F$ hitung dengan $F$ tabel. Nilai $F$ hitung dapat dilihat dari hasil pengolahan data anova. Nilai $F$ tabel dengan nilai signifikan $5 \%$ dan degress of freedom (df) dengan dk penyebut 5 adalah sebesar 9,55 hasil pengolahan data diketahui bahwa nilai $F$ hitung sebesar 47,600 sehingga nilai $F$ hitung $>F$ tabel, artinya bahwa harga jual dan saluran distribusi secara simultan (bersama-sama) terbukti berpengaruh terhadap volume penjualan.

\section{E. KESIMPULAN}

Berdasarkan permasalahan dan pembahasan yang telah dilakukan, dapat ditarik kesimpulan sebagai berikut:

1. Persamaan regresi yang didapat adalah : $Y=1960+(-0,20) X_{1}+0,90 X_{2}+$ e.

Persamaan tersebut dapat disimpulkan bahwa tanpa adanya variabel harga jual $\left(\mathrm{X}_{1}\right)$, variabel saluran distribusi $\left(\mathrm{X}_{2}\right)$, maka nilai volume penjualan $(\mathrm{Y})$ sebesar 1960. Apabila variabel harga jual $\left(X_{1}\right)$ dinaikan satu-satuan maka akan meningkatkan sementara variabel volume penjualan $(Y)$ negatif sebesar $(-0,20)$. Apabila saluran distribusi $\left(\mathrm{X}_{2}\right)$ dinaikan satu-satuan maka akan meningkatkan sementara variabel volume penjualan $(Y)$ sebesar 0,90 .

2. Nilai $F$ tabel dengan nilai signifikan $5 \%$ dan degress of freedom (df) dengan $\mathrm{dk}$ penyebut 5 adalah sebesar 9,55 hasil pengolahan data diketahui bahwa nilai $F$ hitung sebesar 47,600 sehingga nilai $F$ hitung $>F$ tabel. Sehingga dapat disimpulkan ada pengaruh antara variabel harga jual $\left(X_{1}\right)$ dan variabel saluran 
distribusi $\left(\mathrm{X}_{2}\right)$ berpengaruh secara bersama-sama signifikan terhadap volume penjualan paket internet telkomsel 15GB pada CV. Sinar Telekom Lahat.

3. Dengan tingkat signifikan $5 \%$. Dan membandingkan nilai signifikan (sig) 0,060>0,050 maka Ho diterima dan Ha ditolak, hal ini menunjukkan bahwa tidak terdapat pengaruh yang signifikan antara harga jual dan volume penjualan paket internet telkomsel 15GB pada CV. Sinar Telekom Lahat. Variabel saluran distribusi tingkatsignifikan (Sig) 0,011>0,050 maka Ho ditolak dan Ha diterima, hal ini menunjukkan bahwa terdapat pengaruh signifikan antara saluran distribusi dan volume penjualan paket internet telkomsel 15GB pada CV. Sinar Telekom Lahat.

4. Besarnya nilai koefisien determinasi $\left(r^{2}\right)$ pada tabel pengolahan data SPSS sebesar 97,9. Artinya variabel volume penjualan paket internet telkomsel 15GB pada CV. Sinar Telekom Lahat dapat dijelaskan oleh variabel harga jual dan saluran distribusi dengan kontribusi $97,9 \%$ sedangkan sisanya 2,1 dapat dijelaskan variabel lain yang tidak dimasukkan dalam model penelitian ini.

\section{DAFTAR PUSTAKA}

Abdullah, Thamrin dan Francis Tantri. 2016. Manajemen Pemasaran. Depok: PT Raja Grafindo Persada.

Armstrong, Kotler. 2015. Marketing an Introducing Prentice Hall twelfth Edition. England: Pearson Education, Inc.

Kotler, Philip and Kevin Lane Keller. 2016. Marketing Manajemen, 15th Edition New Jersey: Pearson Pretice Hall, Inc.

Kotler, Philip and Gary Amstrong. 2016. Prinsip-prinsip Pemasaran. Edisi 13. Jilid 1. Jakarta: Erlangga.

Sugiyono. 2017. Statistika Untuk Penelitian. Penerbit Alpabeta, Bandung 